\title{
Milk production responses to a change in dietary starch concentration vary by production level in dairy cattle
}

\author{
J. P. Boerman, S. B. Potts, M. J. VandeHaar, M. S. Allen, and A. L. Lock ${ }^{1}$ \\ Department of Animal Science, Michigan State University, East Lansing 48824
}

\begin{abstract}
The effects of dietary starch concentration on yield of milk and milk components were evaluated in a crossover design experiment. Holstein cows $(\mathrm{n}=32 ; 115 \pm 22 \mathrm{~d}$ in milk) with a wide range in milk yield (28 to $62 \mathrm{~kg} / \mathrm{d}$ ) were assigned randomly within level of milk yield to a treatment sequence. Treatments were diets containing $30 \%$ dry ground corn (CG) or $30 \%$ soyhulls $(\mathrm{SH})$ on a DM basis. Diets containing corn silage and alfalfa silage were formulated to contain $16 \%$ crude protein, $24 \%$ forage neutral detergent fiber, and either 27 or $44 \%$ neutral detergent fiber and 30 or $12 \%$ starch for CG and $\mathrm{SH}$, respectively. Cows were fed a diet intermediate to the treatments during a preliminary $14-\mathrm{d}$ period. Treatment periods were $28 \mathrm{~d}$ with measurements taken throughout the period for energy calculations and the final $5 \mathrm{~d}$ used for data and sample collection for production variables. Compared with $\mathrm{SH}, \mathrm{CG}$ increased dry matter intake, and yields of milk, milk protein, milk fat, and energy-corrected milk, as well as milk protein concentration. Treatment did not affect milk fat concentration. Yield of de novo synthesized and preformed milk fatty acids increased with CG. Treatment interacted with level of preliminary milk production for several response variables (yields of milk, milk protein, milk fat, energy-corrected milk, and $3.5 \%$ fat-corrected milk). Compared with $\mathrm{SH}$, the $\mathrm{CG}$ treatment increased energy-corrected milk in higher-producing cows with a lesser response to CG as milk yield decreased. The CG treatment increased milk:feed compared with the SH treatment, but not body weight or body condition score. In conclusion, higher-producing cows benefited from the high-starch diet, and lower-producing cows were able to maintain production when most of the starch was replaced with nonforage fiber.
\end{abstract}

Key words: diet starch concentration, feed efficiency, variation in treatment response, energy partitioning

Received October 20, 2014.

Accepted March 30, 2015.

${ }^{1}$ Corresponding author: allock@msu.edu

\section{INTRODUCTION}

Corn grain is typically substituted for forage in dairy cattle diets to increase the energy density of the ration providing glucose precursors for milk production and substrates for microbial protein production. Competition for corn is increasing because of increasing use for human food and biofuels (Edgerton, 2009). Identifying alternative feedstuffs that provide energy and maintain milk component yields will decrease dependence on high-starch ingredients such as corn. Nonforage fiber sources (NFFS) have been researched as alternatives to starch for lactating dairy cattle (e.g., Firkins and Eastridge, 1992; Ipharraguerre et al., 2002; Voelker and Allen, 2003; Mahjoubi et al., 2009). For example, soyhulls have been effectively used in diets because of their high energy density, low filling effect, and highly digestible NDF. Soyhulls, however, are not as rapidly digestible in the rumen as starch sources, so they could improve rumen $\mathrm{pH}$ (Firkins, 1997) but yield fewer glucose precursors compared with corn.

Previous studies have compared the effects of NFFS and starch on milk production. Ipharraguerre et al. (2002) determined the effect of replacing dry ground corn with soyhulls at concentrations from 0 to $40 \%$ diet DM in low-producing dairy cattle $(30 \mathrm{~kg} / \mathrm{d})$, and Voelker and Allen (2003) determined the effect of replacing high-moisture corn with beet pulp at concentrations up to $24 \%$ diet DM. In both experiments, substitution of NFFS for corn did not affect milk yield and, in one case, increased milk fat yield (Ipharraguerre et al., 2002). Both studies, however, observed a reduction in DMI at the highest levels of NFFS inclusion, likely because physical fill was beginning to limit feed intake (Allen, 2000).

Cows varying in milk production have previously been reported to respond differently to diets differing in the ratio of forage to concentrate (Voelker at al., 2002 ) and the ruminal fermentability of starch (Bradford and Allen, 2004). A low-forage diet increased DMI linearly as preliminary milk yield increased compared with a high-forage diet. However, 3.5\% FCM increased quadratically as preliminary milk yield increased, but the response was positive only for cows over $\sim 45 \mathrm{~kg} / \mathrm{d}$ 
of milk (Voelker at al., 2002). Compared with dry corn, high-moisture corn decreased 3.5\% FCM and fat yields for low-producing cows but increased 3.5\% FCM and fat yields for high-producing cows (Bradford and Allen, 2004). Although treatment responses to changes in ratio of forage to concentrate and ruminal starch fermentability differed with level of milk production, we are uncertain if the same is true for changes in the concentration of starch in the diet with the same concentration of forage NDF across levels of milk production. This information is important to aid the optimum allocation of feeds by production level of dairy cows.

Based on these previous findings, our objectives were 2-fold: first, to determine the effects of starch concentration in diets with the same concentration of forage NDF on DMI, nutrient digestibility, yields of milk and milk components, and feed efficiency, and second, to evaluate whether responses to dietary treatments differ for cows varying in milk yield. We hypothesized that low-producing cows are able to maintain milk yield on a low-starch diet, whereas higher-producing cows require higher-starch diets to achieve maximum milk production.

\section{MATERIALS AND METHODS}

\section{Design and Treatments}

Experimental procedures were approved by the Institutional Animal Care and Use Committee at Michigan State University. Thirty-two midlactation $(115 \pm 22$ DIM, mean \pm SD; range 77 to 148 DIM) Holstein cows (7 primiparous, 25 multiparous) with a wide range in milk yield (28 to $62 \mathrm{~kg} / \mathrm{d}$ ) from the Michigan State University Dairy Field Laboratory were randomly assigned to treatment sequence in a crossover design experiment with 28 -d periods preceded by a $14-d$ preliminary period. Measurements were taken throughout periods for energy calculations and the final $5 \mathrm{~d}$ of each period used for data and sample collection for production and digestibility variables.

Treatments consisted of diets containing either ground corn grain $(\mathbf{C G})$ or soyhulls $(\mathbf{S H})$ at $30 \%$ diet DM. The diet fed during the preliminary period was intermediate between the 2 diets. Diets were based on corn silage and alfalfa silage as the major forage components. The ingredient and nutrient composition of the diets fed as TMR are described in Table 1. Minerals and vitamins were formulated according to NRC (2001) recommendations. The DM concentration of forages was determined twice weekly, and diets were adjusted when necessary. All cows were housed in the same tie-stall throughout the entire experiment and milked twice daily (0430 and $1530 \mathrm{~h})$. Access to feed
Table 1. Ingredients and nutrient composition of experimental $\operatorname{diets}^{1}$

\begin{tabular}{lcc}
\hline & \multicolumn{2}{c}{ Treatment } \\
\cline { 2 - 3 } Item & CG & SH \\
\hline Ingredient (\% of DM) & & \\
Corn silage & 22.5 & 22.5 \\
Alfalfa silage & 22.5 & 22.5 \\
Wheat straw & 5.0 & 5.0 \\
Ground corn & 30.0 & 3.6 \\
Soyhulls & - & 30.0 \\
Soybean meal & 17.0 & 13.7 \\
Vitamin and mineral mix ${ }^{2}$ & 2.0 & 2.0 \\
Limestone & 0.50 & - \\
Sodium bicarbonate & 0.50 & 0.50 \\
Dicalcium phosphate & - & 0.25 \\
Nutrient composition (\% of DM) & & \\
DM & \\
NDF & 53.9 & 53.6 \\
Forage NDF & 27.2 & 43.9 \\
Starch & 23.6 & 23.9 \\
CP & 30.1 & 12.2 \\
FA & 16.5 & 15.9 \\
\hline
\end{tabular}

${ }^{1}$ Average composition of experimental diets fed to 32 cows in a crossover design with 28-d periods. Values based on nutrient composition of individual ingredients sampled the last $5 \mathrm{~d}$ of each period. Treatments contained $30 \%$ dried ground corn (CG) or $30 \%$ soyhulls $(\mathrm{SH})$ on a DM basis.

${ }^{2}$ Vitamin and mineral mix contained $34.1 \%$ dry ground shell corn, $25.6 \%$ white salt, $21.8 \%$ calcium carbonate, $9.1 \%$ Biofos (The Mosaic Co., Plymouth, MN), 3.9\% magnesium oxide, $2 \%$ soybean oil, and $<1 \%$ of each of the following: manganese sulfate, zinc sulfate, ferrous sulfate, copper sulfate, iodine, cobalt carbonate, vitamin E, vitamin A, vitamin $\mathrm{D}$, and selenium.

${ }^{3}$ Expressed as percent of as fed.

was blocked from 1000 to $1200 \mathrm{~h}$ to allow for collecting orts and offering feed. Cows were fed $115 \%$ of expected intake at $1200 \mathrm{~h}$ daily. Water was available ad libitum in each stall, and stalls were bedded with sawdust and cleaned twice daily.

\section{Data and Sample Collection for Production and Digestibility Variables}

Milk yield was recorded for each milking during the last $3 \mathrm{~d}$ of the preliminary period when cows were offered the common diet. For production and digestibility responses, samples and data were collected during the last $5 \mathrm{~d}$ of each treatment period. Samples of all diet ingredients $(0.5 \mathrm{~kg})$ and orts from each cow (12.5\%) were collected daily (d 24 to 28) and composited by period for analysis. Milk yield was recorded, and 2 milk samples were collected at each milking (d 24 to 28). One aliquot was collected in a sealed tube with preservative (bronopol tablet; D\&F Control Systems, San Ramon, $\mathrm{CA}$ ) and stored at $4^{\circ} \mathrm{C}$ for milk component analysis. The second aliquot was stored without preservative at $-20^{\circ} \mathrm{C}$ until analysis for FA composition. Fecal $(\sim 400$ g) grab samples were collected every $15 \mathrm{~h}$ for the last 5 
$\mathrm{d}$ of each period (d 24 to 28 ) resulting in 8 samples per cow per period, representing every $3 \mathrm{~h}$ of a 24 -h period to account for diurnal variation. Fecal samples were stored at $-20^{\circ} \mathrm{C}$ until they were dried, ground, and composited on an equal DM basis per cow each period.

\section{Sample Analysis}

Diet ingredients, orts, and fecal samples were dried at $55^{\circ} \mathrm{C}$ in a forced-air oven for $72 \mathrm{~h}$ for DM determination. Dried samples were ground with a Wiley mill (1-mm screen; Arthur H. Thomas, Philadelphia, PA). Diet ingredients were analyzed for NDF, indigestible NDF, CP, and starch as described by Kammes and Allen (2012). Indigestible NDF was measured as NDF after $240 \mathrm{~h}$ of in vitro fermentation (Goering and Van Soest, 1970) using rumen fluid from a nonlactating mature cow fed dry hay. The concentration of FA in feed ingredients was determined as described by Lock et al. (2013).

Individual milk samples were analyzed for fat, true protein, and lactose concentration by midinfrared spectroscopy (AOAC, 1990, method 972.160) by the Michigan Dairy Herd Improvement Association (Universal Lab Services, Lansing, MI). Yields of 3.5\% FCM, ECM (NRC, 2001), and milk components were calculated using milk yield and component concentrations for each milking, summed for a daily total, and averaged for each collection period.

A single milk sample per period for each cow was used for analysis of FA composition. Samples were composited based on milk fat yield (d 24-28 of each treatment period). Milk lipids were extracted and FAME prepared according to our methods described previously (Lock et al., 2013). Quantification of FA composition covering $\sim 70 \mathrm{FA}$ in the range $\mathrm{C} 4: 0$ to $\mathrm{C} 24: 0$ was determined using GLC with a CP-Sil 88 WCOT fused silica column $(100 \mathrm{~m} \times 0.25 \mathrm{~mm}$ i.d. $\times 0.2 \mu \mathrm{m}$ film thickness; Varian Inc., Lake Forest, CA) as described by Lock et al. (2013). Yields of individual FA (g/d) in milk fat were calculated by using milk fat yield and FA concentration to determine yield on a mass basis using the molecular weight of each FA while correcting for glycerol content and other milk lipid classes (Piantoni et al., 2013).

\section{Calculations for Energy Partitioning and Dietary Energy Concentration}

Energy partitioning was determined during treatment periods from weekly milk samples taken from 4 consecutive milkings and analyzed for fat, protein, and lactose concentrations (Universal Lab Services), BW measurements 5 times per week following the morn- ing milking, and BCS determined by 3 trained investigators on a 5-point scale (in 0.25-point increments; Wildman et al., 1982) on the last day of each period. These values were used to calculate milk energy output, metabolic BW, and body tissue gain throughout treatment periods.

Milk energy output (MCal/d) for a cow was estimated according to the NRC (2001) with an adjustment for the coefficient from $\mathrm{CP}$ to true protein:

$$
\begin{aligned}
& \text { Milk energy output }(\mathrm{Mcal} / \mathrm{d})=[9.29 \times \text { fat }(\mathrm{kg}) \\
& +5.63 \times \text { true protein }(\mathrm{kg})+3.95 \times \text { lactose }(\mathrm{kg})]
\end{aligned}
$$

where each component was based on the average output of a cow during the 28-d period. Metabolic BW (MBW) was $\mathrm{BW}^{0.75}$, where $\mathrm{BW}$ was the mean $\mathrm{BW}$ for the cow during the 28-d period. Mean daily BW change $(\mathrm{kg})$ was calculated for each cow within period by linear regression after 2 iterations of removing outliers. Energy expended for body energy gain (Mcal/d) was estimated according to the NRC (2001):

$$
\begin{gathered}
\text { Body energy gain }(\mathrm{Mcal} / \mathrm{d})= \\
{[(2.88+1.036 \times \mathrm{BCS}) \times \Delta \mathrm{BW}],}
\end{gathered}
$$

where BCS was the average BCS for a cow during the 28-d period.

Energy concentration of the diet was calculated using 2 methods: (1) based on nutrient digestibility using indigestible NDF as the internal marker and calculated using equations (NRC, 2001) according to Harvatine and Allen (2006); (2) based on the sum of milk energy output, maintenance energy calculated from MBW, and body energy gain divided by DMI for each cow on each diet. Energy partitioning was predicted based on observed performance: $\%$ to milk, maintenance, or body tissue $=[$ milk energy output, $0.08 \times \mathrm{MBW}$, or body energy gain $/$ (milk energy output $+0.08 \times \mathrm{MBW}$ + body energy gain $) \times 100$ ], where $\%$ to milk, maintenance, or body tissue is the percentage of energy partitioned to milk production, maintenance requirement, or body energy gain, respectively. All energy calculations and results are based on net energy for lactation.

\section{Statistical Analysis}

All data were analyzed using the fit model procedure of JMP (version 10; SAS Institute Inc., Cary, NC). Preliminary milk was used as a covariate and was calculated as the mean daily milk production for the last $3 \mathrm{~d}$ of the preliminary period. Data were analyzed using the following model: 


$$
\begin{aligned}
Y_{i j k}=\mu & +C_{i}+P_{j}+T_{k}+\text { pMilk }+T_{k} \times \text { pMilk } \\
& + \text { pMilk }^{2}+T_{k} \times \text { pMilk }^{2}+e_{i j k},
\end{aligned}
$$

where $Y_{i j k}=$ the dependent variable, $\mu=$ the overall mean, $C_{i}=$ random effect of cow $(i=1$ to 32$), P_{j}=$ fixed effect of period ( $j=1$ or 2$), T_{k}$ is the fixed effect of treatment ( $k=1$ or 2$)$, pMilk is the linear effect of preliminary milk yield, $T_{k} \times$ pMilk is the interaction between treatment and the linear effect of preliminary milk yield, pMilk $^{2}$ is the quadratic effect of preliminary milk yield, $T_{k} \times$ pMilk $^{2}$ is the interaction between treatment and the quadratic effect of preliminary milk yield, and $e_{i j k}=$ the residual error.

The interaction between period and treatment was initially included in the model and removed because $P$ $>0.20$ for all variables of interest. Interactions between treatment and preliminary milk yield were removed from the model using the same criteria of $P>0.20$. Treatment terms were declared significant at $P \leq 0.05$, and trends were declared at $P \leq 0.10$. All data are expressed as least squares means and standard error of the means, unless otherwise specified.

Three cows were excluded from our results. One cow had mastitis during the preliminary period causing a severe reduction in milk yield, and its data were not used because of our interest in preliminary milk by treatment interactions. Two cows were excluded because they were highly influential outliers using Cook's D test (Cook and Weisberg, 1982) for 3 or more production variables $>0.20$.

\section{RESULTS}

Diets contained $50 \%$ forage on a DM basis, with a 1:1 ratio of corn silage to alfalfa silage and $5 \%$ wheat straw (Table 1). The SH diet contained 30\% soyhulls, by reducing ground corn and making a small reduction in soybean meal to maintain similar protein concentration in both diets. Dietary NDF was 27 and $44 \%$ and starch was 30 and $12 \%$ DM for CG and $\mathrm{SH}$, respectively. Total dietary FA were relatively low for both diets at $2.3 \%$ for $\mathrm{CG}$ and $1.7 \%$ for $\mathrm{SH}$. At the end of the covariate period, BW of cows was $679 \pm 77 \mathrm{~kg}$, milk yield was $41.0 \pm 9.7 \mathrm{~kg} / \mathrm{d}$, milk fat concentration was $3.78 \pm 0.56 \%$, and milk protein concentration was 3.08 $\pm 0.28 \%$ (mean $\pm \mathrm{SD})$.

The SH treatment reduced DMI and milk yield by 6 and $10 \%$, respectively (both $P<0.001$; Table 2 ). We detected a treatment $\times$ preliminary milk yield interaction for milk yield, with the difference in milk yield for SH compared with CG increasingly greater for cows with higher milk yield (linear interaction, $P<0.001$; Figure 1). We observed similar treatment $\times$ preliminary milk yield interactions for yields of fat, protein, lactose, ECM, and $3.5 \%$ FCM (all linear interactions $P<0.05)$. There was no treatment $\times$ preliminary milk yield interaction for DMI.

The SH treatment decreased the yields of milk fat and protein by 11 and $14 \%$ (both $P<0.001$ ) and decreased the concentration of milk protein by $4 \%(P<$ $0.001)$ but did not affect the concentrations of milk fat $(P=0.17)$ and lactose $(P=0.42)$ compared with $\mathrm{CG}$.

Table 2. Dry matter intake, milk production, milk components, feed efficiency, BW, and BCS for cows fed

\begin{tabular}{|c|c|c|c|c|c|}
\hline \multirow[b]{2}{*}{ Variable } & \multicolumn{2}{|c|}{ Treatment $^{1}$} & \multirow[b]{2}{*}{ SEM } & \multicolumn{2}{|c|}{$P$-value ${ }^{2}$} \\
\hline & $\mathrm{CG}$ & $\mathrm{SH}$ & & Trt & Trt $\times$ pMilk \\
\hline DMI $(\mathrm{kg} / \mathrm{d})$ & 28.0 & 26.4 & 0.57 & $<0.001$ & NS \\
\hline \multicolumn{6}{|l|}{ Milk yield $(\mathrm{kg} / \mathrm{d})$} \\
\hline Milk & 38.7 & 34.8 & 0.83 & $<0.001$ & $<0.001$ \\
\hline $3.5 \% \mathrm{FCM}^{3}$ & 40.1 & 36.5 & 0.93 & $<0.001$ & 0.003 \\
\hline $\mathrm{ECM}^{4}$ & 40.3 & 36.3 & 0.89 & $<0.001$ & $<0.001$ \\
\hline \multicolumn{6}{|l|}{ Milk component } \\
\hline $\mathrm{Fat}^{5}(\mathrm{~kg} / \mathrm{d})$ & 1.45 & 1.29 & 0.05 & $<0.001$ & 0.02 \\
\hline Fat $(\%)$ & 3.77 & 3.85 & 0.10 & 0.17 & NS \\
\hline Protein $(\mathrm{kg} / \mathrm{d})$ & 1.27 & 1.09 & 0.03 & $<0.001$ & $<0.001$ \\
\hline Protein (\%) & 3.32 & 3.18 & 0.05 & $<0.001$ & NS \\
\hline Lactose $(\mathrm{kg} / \mathrm{d})$ & 1.88 & 1.68 & 0.05 & $<0.001$ & $<0.001$ \\
\hline Lactose $(\%)$ & 4.85 & 4.83 & 0.03 & 0.42 & NS \\
\hline ECM/DMI & 1.45 & 1.39 & 0.04 & 0.01 & NS \\
\hline
\end{tabular}
treatment diets $(\mathrm{n}=29$; data collected d 24 to 28 of each treatment period)

${ }^{1}$ Treatments contained $30 \%$ dried ground corn (CG) or $30 \%$ soyhulls $(\mathrm{SH})$ on a DM basis.

${ }^{2} P$-value associated with treatment differences (CG vs. SH; Trt) and the linear interaction between treatment and preliminary milk yield (Trt $\times$ pMilk). NS $=$ the interaction between treatment and preliminary milk yield was initially included in the model and removed because $P>0.20$.

${ }^{3} 3.5 \% \mathrm{FCM}=[(0.4324 \times \mathrm{kg}$ of milk $)+(16.216 \times \mathrm{kg}$ of milk fat $)]$.

${ }^{4} \mathrm{ECM}=[(0.327 \times \mathrm{kg}$ of milk $)+(12.95 \times \mathrm{kg}$ of milk fat $)+(7.20 \times \mathrm{kg}$ of milk protein $)]$.

${ }^{5}$ Significant treatment $\times$ quadratic preliminary milk yield interaction $(P=0.05)$. 


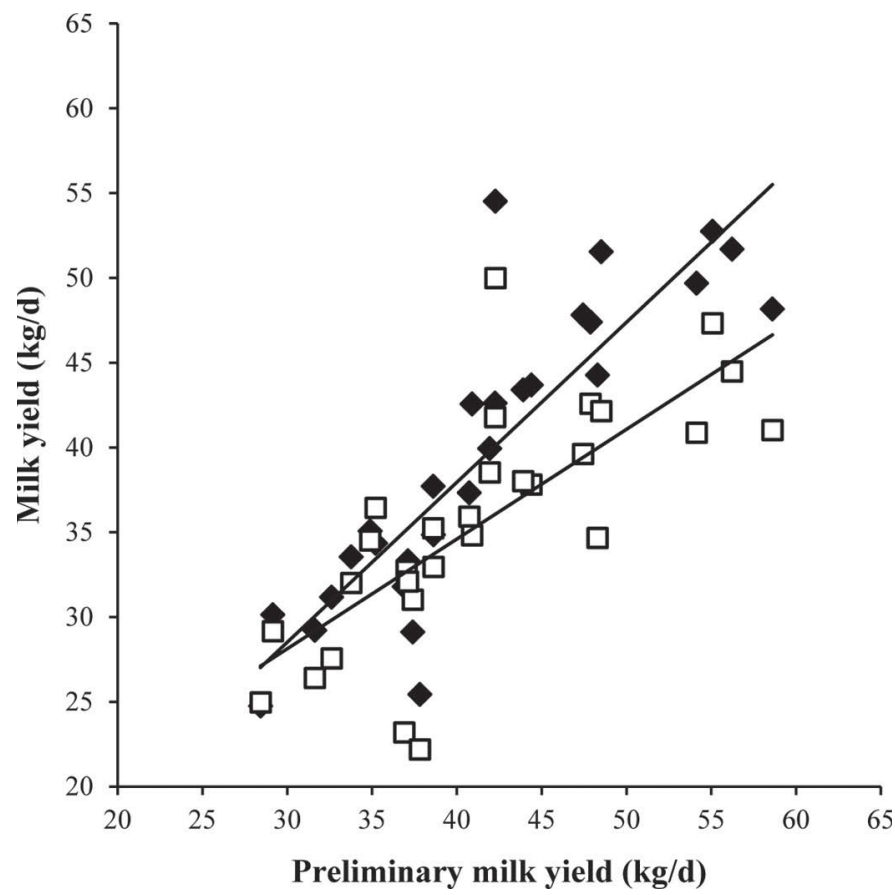

Figure 1. Relationship between milk yield $(\mathrm{kg} / \mathrm{d})$ and preliminary milk yield $(\mathrm{kg} / \mathrm{d})$ for cows $(\mathrm{n}=29)$ fed $30 \%$ dry ground corn $(\mathrm{CG})$ or $30 \%$ soyhulls $(\mathrm{SH})$. CG $(\checkmark)$ : milk yield $(\mathrm{kg} / \mathrm{d})=0.19+0.94 \times$ preliminary milk yield $(\mathrm{kg})\left(\mathrm{R}^{2}=0.75 ; P<0.001\right)$. $\mathrm{SH}(\square)$ : milk yield $(\mathrm{kg} / \mathrm{d})$ $=8.72+0.65 \times$ preliminary milk yield $(\mathrm{kg})\left(\mathrm{R}^{2}=0.56 ; P<0.001\right)$.
The SH treatment reduced milk:feed (ECM/DMI) by $4 \%(P=0.01)$. Treatment did not affect BW $(P=$ $0.11)$ or BCS $(P=0.62$; Table 3$)$.

Calculated milk energy output was greater for CG than SH $(P<0.001$; Table 3$)$ and was increasingly greater for cows with greater preliminary milk yield $(P$ $=0.04$ for treatment $\times$ preliminary milk yield interaction). Daily change in $\mathrm{BW}(\mathrm{kg} / \mathrm{d})$ and body energy gain (Mcal/d) were similar for treatments (both $P>$ $0.10)$. Dietary energy values based on animal performance and digestible nutrients indicated that the CG treatment tended to contain $5 \%(P=0.07)$ and $6 \%(P$ $<0.001)$ more Mcal of $\mathrm{NE}_{\mathrm{L}} / \mathrm{kg}$ than the $\mathrm{SH}$ treatment, respectively. The percentages of energy partitioned to milk $(P=0.99)$ and used for body energy gain $(P=$ 0.30 ) were similar for both treatments, whereas the percentage of energy used for maintenance was higher for SH $(P=0.002)$.

Treatment altered the concentration and yield of FA in milk fat according to source $(<16$ carbon FA from de novo synthesis in the mammary gland, $>16$ carbon FA originating from extraction from plasma, and 16-carbon FA originating from mixed sources; Table 4). On a concentration basis, $\mathrm{SH}$ decreased de novo synthesized FA $(P<0.001)$ and preformed milk FA $(P=0.04)$ but increased 16-carbon FA $(<0.001)$. On a yield basis, $\mathrm{SH}$

Table 3. Energy partitioning ${ }^{1}$ for cows fed treatment diets $(\mathrm{n}=29)$

\begin{tabular}{|c|c|c|c|c|c|}
\hline \multirow[b]{2}{*}{ Variable } & \multicolumn{2}{|c|}{ Treatment $^{2}$} & \multirow[b]{2}{*}{ SEM } & \multicolumn{2}{|c|}{$P$-value ${ }^{3}$} \\
\hline & CG & $\mathrm{SH}$ & & Trt & Trt $\times$ pMilk \\
\hline $\mathrm{BW}^{4}(\mathrm{~kg})$ & 691 & 689 & 13.9 & 0.11 & NS \\
\hline $\mathrm{BCS}^{4}$ & 2.76 & 2.75 & 0.08 & 0.62 & NS \\
\hline Change in BW (kg/d) & 0.54 & 0.34 & 0.10 & 0.19 & NS \\
\hline Change in BCS (points/28 d) & 0.10 & 0.06 & 0.04 & 0.45 & NS \\
\hline \multicolumn{6}{|l|}{ Calculated energy values ${ }^{5}$} \\
\hline Dietary energy ${ }^{6}(\mathrm{Mcal} / \mathrm{kg})$ & 1.69 & 1.59 & 0.02 & $<0.001$ & NS \\
\hline Dietary energy ${ }^{7}(\mathrm{Mcal} / \mathrm{kg})$ & 1.63 & 1.55 & 0.04 & 0.07 & NS \\
\hline Milk (Mcal/d) & 28.5 & 26.0 & 0.60 & $<0.001$ & 0.04 \\
\hline BW change $(\mathrm{kg} / \mathrm{d})$ & 0.54 & 0.34 & 0.10 & 0.19 & NS \\
\hline Body energy gain (Mcal/d) & 3.13 & 1.93 & 0.57 & 0.16 & NS \\
\hline Maintenance (Mcal/d) & 10.8 & 10.7 & 0.16 & 0.13 & NS \\
\hline \multicolumn{6}{|l|}{ Partitioning } \\
\hline Milk (\% energy intake) & 67.1 & 67.1 & 1.34 & 0.99 & NS \\
\hline BW gain ( $\%$ energy intake) & 6.93 & 4.67 & 1.46 & 0.30 & NS \\
\hline Maintenance (\% energy intake) & 25.9 & 28.2 & 0.77 & 0.002 & NS \\
\hline
\end{tabular}

${ }^{1}$ Based on animal performance throughout the $28-\mathrm{d}$ periods unless otherwise stated.

${ }^{2}$ Treatments contained $30 \%$ dried ground corn (CG) or $30 \%$ soyhulls (SH) on a DM basis.

${ }^{3} P$-value associated with treatment differences (CG vs. SH; Trt) and the linear interaction between treatment and preliminary milk yield (Trt $\times$ pMilk). NS $=$ the interaction between treatment and preliminary milk yield was initially included in the model and removed because $P>0.20$.

${ }^{4}$ Mean throughout the 28-d period.

${ }^{5}$ Energy calculations based on net energy for lactation.

${ }^{6}$ From digestibility equations (NRC, 2001) according to Harvatine and Allen (2006) based on nutrient digestibility results collected during the last $5 \mathrm{~d}$ of each treatment period (Table 5 ).

${ }^{7}$ From the sum of milk energy output, maintenance energy calculated from metabolic BW, and body energy gain divided by DMI for each cow on each diet throughout the 28-d period. 
Table 4. Milk FA concentration and yield by sources of FA of cows fed treatment diets $(\mathrm{n}=29)$

\begin{tabular}{|c|c|c|c|c|c|}
\hline \multirow[b]{2}{*}{ Sources of milk FA ${ }^{1}$} & \multicolumn{2}{|c|}{ Treatment $^{2}$} & \multirow[b]{2}{*}{ SEM } & \multicolumn{2}{|c|}{$P$-value ${ }^{3}$} \\
\hline & $\mathrm{CG}$ & $\mathrm{SH}$ & & Trt & Trt $\times$ pMilk \\
\hline \multicolumn{6}{|c|}{ FA concentration $(\mathrm{g} / 100 \mathrm{~g})$} \\
\hline De novo & 29.1 & 28.8 & 0.31 & $<0.001$ & NS \\
\hline Mixed & 35.4 & 37.9 & 0.41 & $<0.001$ & NS \\
\hline Preformed & 34.7 & 34.0 & 0.44 & 0.04 & NS \\
\hline \multicolumn{6}{|l|}{ FA yield $(\mathrm{g} / \mathrm{d})$} \\
\hline De novo & 403 & 351 & 14.6 & $<0.001$ & NS \\
\hline Mixed & 480 & 476 & 19.8 & 0.69 & NS \\
\hline Preformed & 465 & 421 & 11.7 & $<0.001$ & 0.02 \\
\hline
\end{tabular}

${ }^{1}$ De novo FA originate from mammary de novo synthesis ( $<16$ carbons), preformed FA originate from extraction from plasma ( $>16$ carbons), and mixed FA originate from both sources (C16:0 plus cis-9 C16:1). A total of approximately 80 individual FA were quantified and used for calculations (summation by source).

${ }^{2}$ Treatments contained $30 \%$ dried ground corn (CG) or $30 \%$ soyhulls (SH) on a DM basis.

${ }^{3} P$-value associated with treatment differences (CG vs. SH; Trt) and the linear interaction between treatment and preliminary milk yield (Trt $\times$ pMilk). NS $=$ the interaction between treatment and preliminary milk yield was initially included in the model and removed because $P>0.20$.

decreased both de novo and preformed milk FA (both, $P<0.001)$ with no difference in 16-carbon milk FA (Table 4). A significant treatment $\times$ preliminary milk yield interaction was detected for preformed milk FA yield $(P=0.02)$, which parallels the interaction observed for milk yield. Compared with $\mathrm{CG}$, the $\mathrm{SH}$ treatment decreased the concentration $(0.24$ vs. $0.32 \mathrm{~g} / 100 \mathrm{~g}$ of FA) and yield (2.94 vs. $4.22 \mathrm{~g} / \mathrm{d}$ ) of trans-10 C18:1 in milk, but the concentration and yield of trans-10, cis-12 C18:2 was below detectable limits for all samples.

Apparent total-tract digestibility of NDF and DM were affected by treatment (Table 5). Digestibility of NDF increased for $\mathrm{SH}$ compared with $\mathrm{CG}$ (53 vs. $40 \% ; P<0.001)$ for all cows, with a greater difference in NDF digestibility between treatments for higherproducing cows (interaction $P<0.01$; Figure 2). The interaction was because NDF digestibility decreased as preliminary milk yield increased for CG $(P<0.001)$, but there was no relationship between NDF digestibility and preliminary milk yield for $\mathrm{SH}(P=0.61$, Figure $2)$. Digestibilities of starch and $\mathrm{CP}$ were unaffected by treatment $(P=0.81$ and $P=0.29$, respectively; Table
5), but SH decreased DM digestibility compared with CG (66 vs. $68 \%, P<0.001)$.

\section{DISCUSSION}

Previous research has evaluated the effects of diets high in NFFS (relatively low in starch) compared with higher-starch diets containing corn grain (e.g., Ipharraguerre et al., 2002; Voelker and Allen, 2003). These studies reported that NFFS could be included in the diet at high levels (30 and 24\% DM, respectively) with no detrimental effects on production parameters. However, the cows in these studies had only moderate milk yield (30 and $36 \mathrm{~kg} / \mathrm{d}$, respectively). We postulated that results might differ for higher-producing cows with greater glucose requirements. Variation in production response, dependent on level of milk production, has been previously reported in diets differing in ratio of forage to concentrate (Voelker et al., 2002) and starch source (Bradford and Allen, 2004). Therefore, in our current study, cows with a wide range of milk yield $(28$ to $62 \mathrm{~kg} / \mathrm{d}$ ) during the preliminary period were used to

Table 5. Nutrient digestibility of cows fed treatment diets $(\mathrm{n}=29)$

\begin{tabular}{|c|c|c|c|c|c|}
\hline \multirow[b]{2}{*}{ Nutrient } & \multicolumn{2}{|c|}{ Treatment $^{1}$} & \multirow[b]{2}{*}{ SEM } & \multicolumn{2}{|c|}{$P$-value ${ }^{2}$} \\
\hline & $\mathrm{CG}$ & $\mathrm{SH}$ & & Trt & Trt $\times$ pMilk \\
\hline $\mathrm{DM}$ & 68.3 & 65.5 & 0.37 & $<0.001$ & NS \\
\hline $\mathrm{NDF}$ & 39.6 & 53.4 & 0.65 & $<0.001$ & 0.01 \\
\hline Starch & 94.2 & 94.1 & 0.36 & 0.81 & NS \\
\hline $\mathrm{CP}$ & 68.9 & 68.3 & 0.44 & 0.29 & NS \\
\hline
\end{tabular}


4704

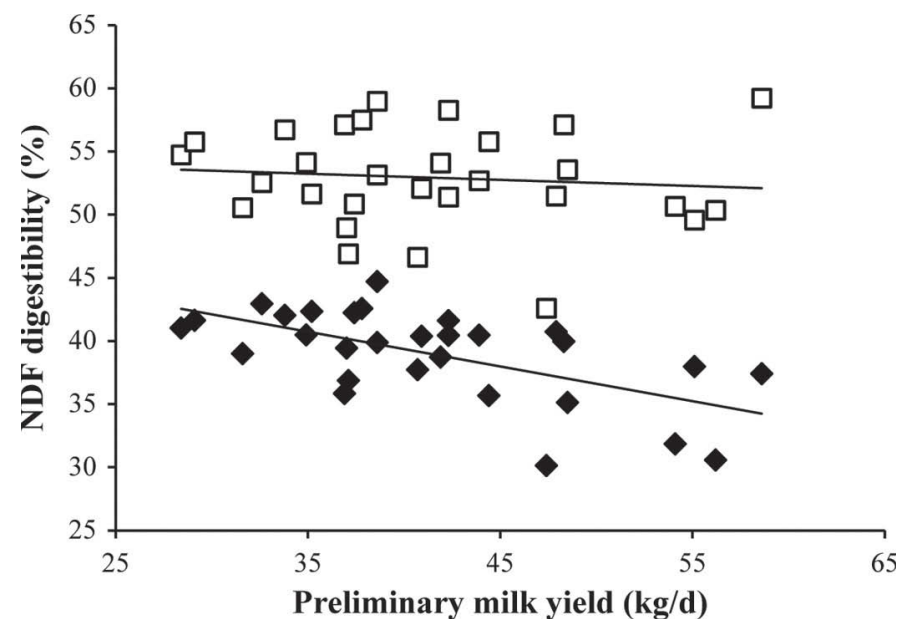

Figure 2. Relationship between NDF digestibility (\%) and preliminary milk yield $(\mathrm{kg} / \mathrm{d})$ for cows $(\mathrm{n}=29)$ fed $30 \%$ dry ground corn $(\mathrm{CG})$ or $30 \%$ soyhulls (SH). CG $($ ): NDF digestibility $\%=50.33-$ $0.27 \times$ preliminary milk yield $(\mathrm{kg})\left(\mathrm{R}^{2}=0.37 ; P<0.001\right)$. SH $(\square)$ : NDF digestibility $\%=54.94-0.05 \times$ preliminary milk yield $(\mathrm{kg})\left(\mathrm{R}^{2}\right.$ $=0.01 ; P=0.61$ )

evaluate effects of diets differing in starch concentrations.

The forage composition of both diets was the same so forage NDF remained constant. The SH treatment reduced DMI compared with CG, consistent with previous results when soyhulls were substituted for corn grain at $30 \%$ of diet DM (Ipharraguerre et al., 2002). This is likely because some cows were limited by physical fill. Although NFFS generally have little effect on DMI when substituted in the diet for grains (Allen, 2000), soyhulls likely digest and pass from the rumen more slowly than corn grain and physical fill might already have been limiting DMI for some cows. In our current experiment, forage NDF concentration $(\sim 24 \%)$ was relatively high given the mean milk yield of these cows $(40 \mathrm{~kg} / \mathrm{d}$ of ECM for the CG treatment). Forage NDF concentration is filling relative to other diet fractions, and ruminal fill is a greater limitation to DMI as milk yield increases (Allen, 2000). Given the high forage NDF concentration of the diets, the additional filling effect of SH treatment, even if small, may have been sufficient compared with CG to cause the reduction in DMI.

Failure to detect an interaction for DMI between preliminary milk yield and treatment was not expected. When fed a low-forage diet, compared with a high-forage diet, DMI was greater for higher-producing cows than lower-producing cows (Voelker et al., 2002). Higher-producing cows were able to consume more and meet their energy demands on the low-forage diet because they were not limited by physical fill. We expect- ed that for our current study, if SH reduced DMI, the reduction would be greater as preliminary milk yield of cows increased because rumen fill likely limits feed intake to a greater extent for these cows (Allen, 2000). Additionally, we thought that increased propionate production from CG compared with the $\mathrm{SH}$ treatment might decrease DMI more for lower-producing cows by stimulating hepatic oxidation (Allen et al., 2009). However, rumen distention might have dominated control of feed intake from the high forage NDF concentration of the treatment diets even for the lower-producing cows, and propionate supply might not have been excessive because dry corn is not highly fermentable in the rumen (Allen, 2000). Even though we had a wide range in milk production, the cows were relatively close in DIM. Whether using cows with greater variation in stage of lactation may have resulted in treatment $x$ preliminary milk yield interactions for DMI is not known.

Our 2 treatments contained extreme concentrations of starch relative to diets typically fed to lactating cows. The SH treatment with $12 \%$ starch decreased milk production relative to the CG diet with $30 \%$ starch. However, the cows in this experiment had a wide range of milk yield, and the reduction in milk yield was much less for lower-producing cows with a lower requirement for glucose precursors. At the low end of the range in milk yield $(<30 \mathrm{~kg} / \mathrm{d})$, cows were able to maintain milk yield on the $12 \%$ starch compared with the $30 \%$ starch diet. The treatment $\times$ preliminary milk yield interactions for yields of fat, lactose, ECM, and $3.5 \% \mathrm{FCM}$ were all driven by milk yield, with a greater response to the CG treatment for higher-producing cows and the lower-producing cows able to maintain production on the SH treatment. We calculated dietary energy using 2 methods based on digestible nutrients or cow performance data. In our current study results were relatively consistent across both methods, with the CG treatment providing $\sim 5$ to $6 \%$ more dietary energy than the $\mathrm{SH}$ treatment.

High-producing cows generally have lower plasma insulin concentration and are less insulin sensitive than lower-producing cows, which favors energy partitioning to milk compared with adipose tissue (De Koster and Opsomer, 2013). The CG treatment likely increased the supply of glucose precursors and glucose, allowing greater lactose production and milk yield but also greater insulin secretion. Greater plasma insulin concentration is more likely to partition more energy to adipose tissue, particularly for lower-producing cows that are more insulin sensitive than high-producing cows.

The reduction in milk protein concentration from the SH treatment might have been the result of decreased 
dietary starch concentration. The higher dietary starch in the CG treatment would likely cause an increase in insulin concentrations, and insulin seems to play either a direct or indirect role in milk protein synthesis (Griinari et al., 1997; Mackle et al., 1999; Arriola Apelo et al., 2014). Additionally, the lower dietary starch in the SH treatment may have reduced microbial protein and, in turn, the amount of protein available for milk protein synthesis (Weiss et al., 2011); however, treatment differences in fermentable OM are not known. Finally, the SH diet had $4 \%$ less CP than the CG diet and resulted in $6 \%$ less DMI, both contributing to less protein available for milk protein synthesis.

We expected to see a reduction in milk fat concentration when cows were fed the CG diet. The high starch and relatively low total NDF content of the $\mathrm{CG}$ diet are risk factors for milk fat depression (Bauman et al., 2011). However, we did not observe a reduction in milk fat with CG. This may have been due to (1) the very low concentration of FA in CG $(2.26 \% \mathrm{DM})$ limiting the supply of PUFA to significantly alter rumen fermentation and produce biohydrogenation intermediates associated with milk fat depression; (2) moderate ruminal fermentability of starch in the $C G$ treatment limiting fluctuations in rumen $\mathrm{pH}$; and (3) high rumen buffering capacity from the high concentration of forage NDF ( $87 \%$ of total NDF) maintaining ruminal $\mathrm{pH}$. Notably, we did not detect trans-10, cis-12 C18:2 in any of our milk samples, although we observed increases in trans-10 C18:1 for CG, suggesting that the CG diet did alter biohydrogenation pathways to a limited extent.

The increase in NDF digestibility with the SH treatment in our study is similar to results reported by Voelker and Allen (2003) with $24 \%$ beet pulp compared with high-moisture corn increasing NDF digestibility. Although DM digestibility was increased with added beet-pulp diets (Voelker and Allen, 2003), we observed a reduction in DM digestibility with added NFFS (soyhulls) despite higher NDF digestibility, indicating that the NDF from soyhulls was less digestible than starch from corn grain. The difference in the intercept in Figure 2 (50 vs. 55\% for $\mathrm{CG}$ and $\mathrm{SH}$, respectively) of NDF digestibility is because the NDF from the soyhulls in $\mathrm{SH}$ was more digestible than the NDF in the forages, which supplied the majority of the NDF in CG. However, the change in slope for the treatments could be due to several factors. Cows on CG had higher intake and this change could relate to higher passage rates, which could have reduced the amount of time the NDF was available in the rumen for digestion. Additionally, high-starch diets might have reduced ruminal $\mathrm{pH}$ or altered the microbial population enough to depress fiber digestion.

\section{CONCLUSIONS}

Although we observed distinct differences in treatment means for many production and digestibility parameters, treatment $\times$ preliminary milk yield interactions gave further insight on responses to diets varying in dietary starch concentration. Higher-producing cows responded more negatively to a reduction in starch concentration than low-producing cows, as low-producing cows were able to maintain milk production on the lowstarch diet. The finding that cows at different levels of milk production responded differently to dietary starch content indicates that grouping cows by production level would enable optimum allocation of feeds.

\section{ACKNOWLEDGMENTS}

We acknowledge C. L. Preseault, D. G. Main, and J. S. Liesman (all in the Department of Animal Science, Michigan State University) and the staff of the Michigan State University Dairy Cattle Field Laboratory for their assistance in this experiment. Supported in part by the Agriculture and Food Research Initiative Competitive Grant no. 2011-68004-30340 from the USDA National Institute of Food and Agriculture (to M. J. V.) and Michigan State University AgBioResearch.

\section{REFERENCES}

Allen, M. S. 2000. Effects of diet on short-term regulation of feed intake by lactating dairy cattle. J. Dairy Sci. 83:1598-1624.

Allen, M. S., B. J. Bradford, and M. Oba. 2009. Board Invited Review: The hepatic oxidation theory of the control of feed intake and its application to ruminants. J. Anim. Sci. 87:3317-3334.

AOAC. 1990. Official Methods of Analysis. 15th ed. Assoc. Off. Anal. Chem, Arlington, VA.

Arriola Apelo, S. I., J. R. Knapp, and M. D. Hanigan. 2014. Invited review: Current representation and future trends of predicting amino acid utilization in the lactating dairy cow. J. Dairy Sci. 97:4000-4017.

Bauman, D. E., K. J. Harvatine, and A. L. Lock. 2011. Nutrigenomics, rumen-derived bioactive fatty acids, and the regulation of milk fat synthesis. Annu. Rev. Nutr. 31:299-319.

Bradford, B. J., and M. S. Allen. 2004. Milk fat responses to a change in diet fermentability vary by production level in dairy cattle. J. Dairy Sci. 87:3800-3807.

Cook, R. D., and S. Weisberg. 1982. Monographs on Statistics and Applied Probability: Residuals and Influence in Regression. Chapman Hall, New York, NY.

De Koster, J. D., and G. Opsomer. 2013. Insulin resistance in dairy cows. Vet. Clin. North Am. Food Anim. Pract. 29:299-322.

Edgerton, M. D. 2009. Increasing crop productivity to meet global needs for feed, food, and fuel. Plant Physiol. 149:7-13.

Firkins, J. L., and M. L. Eastridge. 1992. Replacement of forage or concentrate with combinations of soyhulls, sodium bicarbonate, or fat for lactating dairy cows. J. Dairy Sci. 75:2752-2761.

Firkins, J. L. 1997. Effects of feeding nonforage fiber sources on site of fiber digestion. J. Dairy Sci. 80:1426-1437.

Goering, H. K., and P. J. Van Soest. 1970. Forage Fiber Analysis (Apparatus, Reagents, Procedures, and Some Applications). Agric. Handbook No. 379. USDA-Agric. Res. Serv., Washington, DC. 
Griinari, J. M., M. A. McGuire, D. A. Dwyer, D. E. Bauman, D. M. Barbano, and W. A. House. 1997. The role of insulin in the regulation of milk protein synthesis in dairy cows. J. Dairy Sci. 80:2361-2371.

Harvatine, K., and M. Allen. 2006. Effects of fatty acid supplements on milk yield and energy balance of lactating dairy cows. J. Dairy Sci. 89:1081-1091.

Ipharraguerre, I. R., R. R. Ipharraguerre, and J. H. Clark. 2002. Performance of lactating dairy cows fed varying amounts of soyhulls as a replacement for corn grain. J. Dairy Sci. 85:2905-2912.

Kammes, K. L., and M. S. Allen. 2012. Nutrient demand interacts with grass particle length to affect digestion responses and chewing activity in dairy cows. J. Dairy Sci. 95:807-823.

Lock, A. L., C. L. Preseault, J. E. Rico, K. E. DeLand, and M. S. Allen. 2013. Feeding a C16:0-enriched fat supplement increased the yield of milk fat and improved conversion of feed to milk. J. Dairy Sci. 96:6650-6659

Mackle, T. R., D. A. Dwyer, K. L. Ingvartsen, P. Y. Chouinard, J. M. Lynch, D. M. Barbano, and D. E. Bauman. 1999. Effects of insulin and amino acids on milk protein concentration and yield from dairy cows. J. Dairy Sci. 82:1512-1524

Mahjoubi, E., H. Amanlou, D. Zahmatkesh, M. Ghelich Khan, and N Aghaziarati. 2009. Use of beet pulp as a replacement for barley grain to manage body condition score in over-conditioned late lactation cows. Anim. Feed Sci. Technol. 153:60-67.

National Research Council. 2001. Nutrient Requirements of Dairy Cattle. 7th rev. ed. Natl. Acad. Sci., Washington, DC.

Piantoni, P., A. L. Lock, and M. S. Allen. 2013. Palmitic acid increased yields of milk and milk fat and nutrient digestibility across production level of lactating cows. J. Dairy Sci. 96:7143-7154.

Voelker, J. A., and M. S. Allen. 2003. Pelleted beet pulp substituted for high-moisture corn: 1. Effects on feed intake, chewing behavior, and mil production of lactating dairy cows. J. Dairy Sci. $86: 3542-3552$.

Voelker, J. A., G. M. Burato, and M. S. Allen. 2002. Effects of pretrial milk yield on responses of feed intake, digestion, and production to dietary forage concentration. J. Dairy Sci. 85:2650-2661.

Weiss, W. P., J. M. Pinos-Rodriguez, and D. J. Wyatt. 2011. The value of different fat supplements as sources of digestible energy for lactating dairy cows. J. Dairy Sci. 94:931-939.

Wildman, E. E., G. M. Jones, P. E. Wagner, and R. L. Bowman. 1982 A dairy cow body condition scoring system and its relationship to selected production characteristics. J. Dairy Sci. 65:495-501. 